\title{
Survey on Entomopathogens from the Arasbaran Biosphere Reserve (Iran) with a Modified Bait Insect Technique
}

\author{
Eustachio Tarasco ${ }^{1,3}$, Naser Eyvasian Kary ${ }^{2}$, Elena Fanelli ${ }^{3}$, Davoud Mohammadi ${ }^{2}$, Ali Mehrvar ${ }^{2}$, Francesca De Luca ${ }^{3}$ and Alberto \\ Troccoli $^{3}$ \\ ${ }^{1}$ Department of Soil, Plant and Food Sciences, University of Bari "Aldo Moro", via Amendola 165/A, 70126 Bari, Italy \\ ${ }^{2}$ Department of Plant Protection, Azarbaijan Shahid Madani University, Tabriz, Iran \\ ${ }^{3} \mathrm{CNR}$ - IPSP, Istituto per la Protezione Sostenibile delle Piante, Via G. Amendola, 122/D 70126 Bari, Italy
}

${ }^{\star}$ Corresponding author: Eustachio Tarasco, Department of Soil, Plant and Food Sciences, University of Bari "Aldo Moro", via Amendola 165/A, 70126 Bari, Italy; Email: eustachio.tarasco@uniba.it

Received: July 23, 2020; Accepted: August 01, 2020; Published: August 07, 2020

\begin{abstract}
A survey on entomopathogens was carried out in Arasbaran Biosphere Reserve soils during June 2018 using Galleria mellonella L. (Lepidoptera, Pyralidae) larvae as bait insect with a modified bait insect technique. Three entomopathogen's categories were recorded in 34 out of 36 soil samples ( $94.4 \%$ ) collected from different natural habitat; the entomopathogens were identified as nematodes ( $23.5 \%)$, fungi $(61 \%)$ and bacteria (15.5\%) using molecular and morphological techniques.
\end{abstract}

\section{Introduction}

The Arasbaran Biosphere Reserve is situated in the north of Iran and belongs to the Caucasus Iranian Highlands. The area covers high alpine meadows and semi-arid steppes with rangelands, forests, rivers and springs. In these biotopes a survey has been carried out during June 2018, on soil-inhabiting entomopathogens. Soil samples were collected with the aim to evaluate the occurrence especially of entomopathogenic nematodes, fungi and bacteria, as important bioindicator organisms of soil's natural environments. Entomopathogenic nematodes (EPNs) of the genera Steinernema Travassos (Rhabditida, Steinernematidae) and Heterorhabditis Poinar (Rhabditida, Heterorhabditidae) are obligate and lethal parasites of insects [1]. Their non-feeding Infective Juveniles (IJs), usually soil dwelling, hold in their foregut symbiotic bacteria which play an important role in killing susceptible insects. The IJs enter through the insect's mouth, spiracles, anus or through the integument in the case of Heterorhabditis, invade the haemocoel through the mid-gut wall and release bacteria which establish suitable conditions for nematode reproduction by proving nutrients and inhibiting the growth of other microorganisms [2]. The associated bacteria multiply rapidly causing septicemia and death of the host after 24-48 hours, during which time the nematodes feed on the bacteria and reproduce in the cadaver. Entomopathogenic fungi, mainly Hyphomycetes and Ascomycetes, were regularly found infecting insects in soil. The Hyphomycetes, Metarhizium anisopliae (Metch.) Sorokin, and Beauveria bassiana (Bals-Criv.) Vuill. are probably the more known species. These organisms usually attach the external body of insects by conidia.
Under the right conditions of temperature and high humidity, these spores germinate, grow as hyphae and colonize the insect's body. After some days the insect is usually killed (especially by fungal toxins), and new spores are formed in or on the insect, sporulation, ready to be spread in the environment. Entomopathogenic bacteria are the most commercially successful microbial insecticides. They enter the host through ingestion and produce toxins and other pathogenic factors that disrupt the midgut epithelium to allow access to the nutrientrich haemocoel, where they proliferate causing septicemia and death of the host. The most successful microbial pesticide to date is Bacillus thuringiensis Berliner (Bacillales, Bacillaceae) (Bt), a Grampositive soil-dwelling bacterium, which produce crystal proteins during sporulation having insecticidal action. Few is known about the occurrence and importance of these entomopathogens in soils in Arasbaran Region; same data are available for EPNs [3,4] and for EPB $[5,6]$ while, no data are available as regards to the soil inhabiting entomopathogenic fungi. The present survey has been conducted with the aim to contribute to the entomopathogen's biodiversity knowledge, with particular regard to entomophathogenic nematodes, fungi and bacteria, in Arasbaran Reserve soils.

\section{Material and Methods}

A total of 36 soil samples were collected over a period of 4 days during the second half of June 2018 in different biotopes of Arasbaran Biosphere, such as uncultivated soils, woodlands, river borders and grasslands. A hand shovel was used to collect approximately $2 \mathrm{Kg}$ soil comprised each sample by pooling 3-4 sub samples taken at depths of $15-20 \mathrm{~cm}$ from an area of about $20 \mathrm{~m}^{2}$ [7]. The soil was transported in 
Eustachio Tarasco, Naser Eyvasian Kary, Elena Fanelli, Davoud Mohammadi, Ali Mehrvar, et al. (2020) Survey on Entomopathogens from the Arasbaran Biosphere Reserve (Iran) with a Modified Bait Insect Technique

sterile polythene bags to the laboratory and prior baiting, water was added to give a content of $8-10 \%$ moisture and the samples were then stored at room temperature $\left(\sim 26^{\circ} \mathrm{C}\right)$. Final instar larvae of Galleria mellonella L. (Lepidoptera, Pyralidae) were used as bait insects to trap entomopathogens: for each soil sample a total of 8 Galleria larvae were released, 4 inside a long-handled tea infuser placed in the middle of the sample to attract the mobile entomopathogens (as the nematodes), and 4 released free on the top of each sample, to search for the static entomopathogens (as fungi conidia and bacteria spores) (Figure 1). The samples were kept at a room temperature and observations were done after 1 week to monitor the infected and dead larvae. The symptoms of cadavers after infection were recorded and used for diagnosis of EPNs, EPF or EPB induced infection. For the isolation of entomopathogenic nematodes dead larvae from each sample were placed in modified White traps [8] and kept at room temperature $\left(\sim 26^{\circ} \mathrm{C}\right)$. For the nematodes IJs were harvested and stored in distilled water at $8^{\circ} \mathrm{C}$. These nematodes were used to infect fresh G. mellonella larvae and the progeny were used for identification and the establishment of cultures. Measurements were carried out on fresh specimens; the morphometric identification was based on infective juveniles and male morphology [1]. A molecular analysis followed for the EPN strains. For the isolation of entomopathogenic fungi and bacteria, infected wax moth larvae from each sample were surface sterilized by keeping them for $3 \mathrm{~min}$. in $1 \%$ sodium hypochlorite and rinsing them in distilled water. After this, the larvae were incubated at $25^{\circ} \mathrm{C}$ in Petri dishes with moistened filter paper till the presence of pathogens could be assessed. For fungi, when sporulating structures appeared on the cadaver, attempts to isolate the fungus were made by transferring spores to potato dextrose agar in Petri dishes. For bacteria, infected hemolymph was cultured on specific media to isolate the bacteria colonies. For both, EPF and EPB, the inoculated Petri dishes were then checked every day and the tubes with pure cultures were sub-cultured in specific agar medium. Cultures were then stored at $8^{\circ} \mathrm{C}$. For all the EPF and EPB entomopathogens the identification was made with a morphological analysis. For each sampling location, soil texture, time and type of vegetation were recorded (Table 1).
Table 1: Survey in Arasbaran Region (June 2018) - Sampling examination. For each sample habitat, soil texture and infection were recorded. Positive samples 34 of 36: EPN 8; EPF 26 (B: Beauveria, L: Lecanicillium, A: Aspergillus, F: Fusarium); EPB 5; Negative samples 2.

\begin{tabular}{|c|c|c|c|c|c|c|}
\hline \multirow{2}{*}{ Sample } & \multirow{2}{*}{ Habitat } & \multirow{2}{*}{ soil texture } & \multirow{2}{*}{ infection } & \multicolumn{3}{|c|}{ Infected by } \\
\hline & & & & EPN & EPF & EPB \\
\hline 1 & River border & Silty loam & + & * & ${ }^{*} \mathrm{~L}$ & \\
\hline 2 & Corilus wood & Silty loam & + & * & & \\
\hline 3 & Corilus wood & Silty loam & + & & ${ }^{*} \mathrm{~L}$ & \\
\hline 4 & Oak wood & Silty loam & + & & ${ }^{*} \mathrm{~B}$ & \\
\hline 5 & Wild meadow & Silty loam & + & * & ${ }^{*} \mathrm{~L}$ & \\
\hline 6 & River border & Sandy loam & + & & ${ }^{\star} \mathrm{B}$ & \\
\hline 7 & River border & Sandy loam & + & & ${ }^{\star} \mathrm{B}$ & \\
\hline 8 & Oak wood & Silty loam & + & * & & \\
\hline 9 & River border & Silty loam & + & & ${ }^{\star} \mathrm{L}^{\star} \mathrm{A}$ & \\
\hline 10 & Wild meadow & Loamy clay & - & & & \\
\hline 11 & Wild meadow & Loamy clay & + & & ${ }^{*} \mathrm{~B}$ & \\
\hline 12 & Oak wood & loamy clay & + & & ${ }^{\star} \mathrm{B}$ & \\
\hline 13 & Wild meadow & Silty loam & + & * & & \\
\hline 14 & Wild meadow & loamy caly & + & & & * \\
\hline 15 & River border & Silty loam & + & & & * \\
\hline 16 & Wild meadow & Silty loam & + & & ${ }^{*} \mathrm{~B}$ & \\
\hline 17 & Wild meadow & loamy caly & + & & ${ }^{\star} \mathrm{B}$ & \\
\hline 18 & Wild meadow & loamy clay & + & & ${ }^{\star} \mathrm{B}$ & \\
\hline 19 & Apple orchard & Silty loam & + & & ${ }^{\star} \mathrm{L}^{\star} \mathrm{A}^{\star} \mathrm{F}$ & \\
\hline 20 & River border & loamy clay & + & * & & \\
\hline 21 & River border & loamy caly & + & * & & \\
\hline 22 & River border & loamy sand & + & & ${ }^{*} \mathrm{~L}$ & \\
\hline 23 & Wild meadow & Silty loam & + & & & * \\
\hline 24 & Wild meadow & loamy clay & + & & ${ }^{*} \mathrm{~B}$ & \\
\hline 25 & Oak wood & Silty loam & + & & ${ }^{*} \mathrm{~B}$ & \\
\hline 26 & Oak wood & Silty loam & + & & ${ }^{*} \mathrm{~B}$ & \\
\hline 27 & Oak wood & Silty loam & + & & ${ }^{\star} \mathrm{B}$ & \\
\hline 28 & Wild meadow & Silty loam & + & * & & \\
\hline 29 & Wild meadow & Silty loam & + & & & * \\
\hline 30 & Wild meadow & loamy clay & + & & ${ }^{*} \mathrm{~B}$ & \\
\hline 31 & Wild meadow & loamy caly & + & & ${ }^{*} \mathrm{~B}$ & \\
\hline 32 & Corilus wood & Silty loam & + & & & * \\
\hline 33 & Wild meadow & Silty loam & + & & ${ }^{*} \mathrm{~B}$ & \\
\hline 34 & Oak wood & Silty loam & - & & & \\
\hline 35 & Urumy lake & Salty soil & + & & ${ }^{\star} \mathrm{B}$ & \\
\hline 36 & Urumy lake border & Salty beach & + & & ${ }^{\star} \mathrm{B}$ & \\
\hline
\end{tabular}

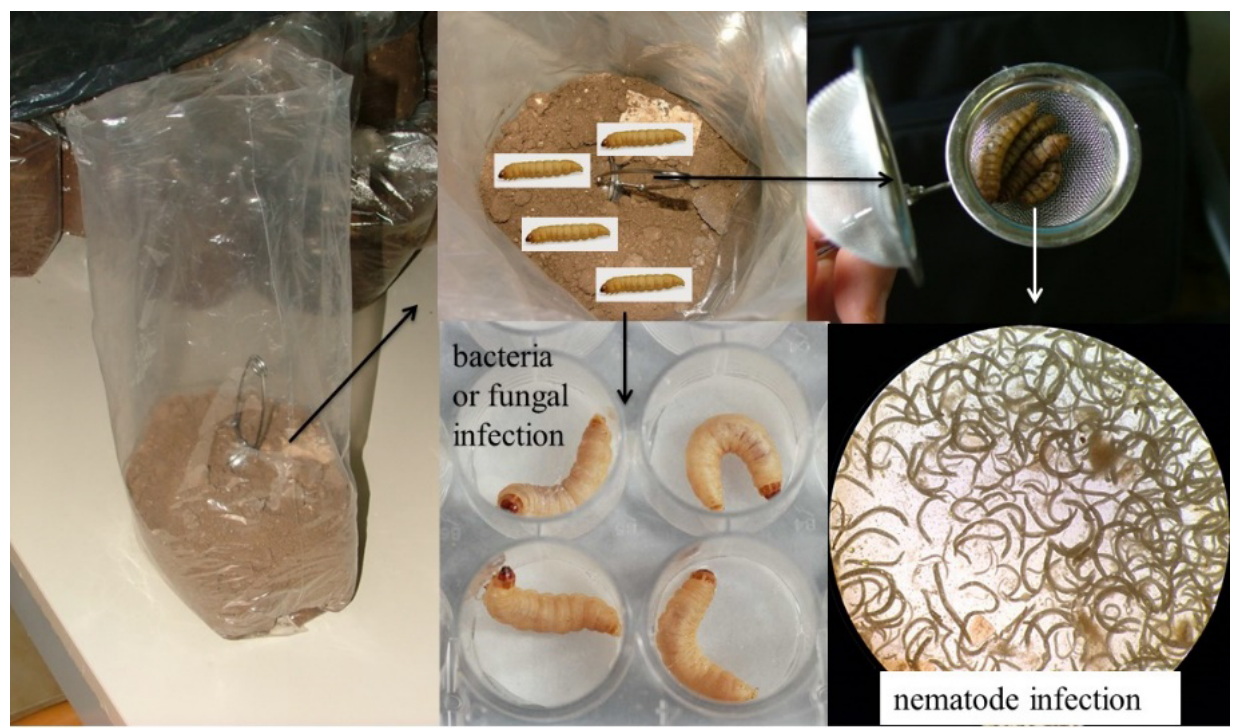

Figure 1: Soil sample with 8 Galleria larvae released, 4 inside a long-handled tea infuser and 4 released free on the top of each sample. 
Eustachio Tarasco, Naser Eyvasian Kary, Elena Fanelli, Davoud Mohammadi, Ali Mehrvar, et al. (2020) Survey on Entomopathogens from the Arasbaran Biosphere Reserve (Iran) with a Modified Bait Insect Technique

\section{Molecular Analysis}

DNA extraction, PCR, cloning and sequencing were performed at IPSP laboratory, (Istituto per la Protezione Sostenibile delle Piante, Bari Italy), following the protocols described [9]. Individual nematodes were hand-picked, placed in $10 \mu \mathrm{l}$ of lysis buffer $(10 \mathrm{mM}$ Tris- $\mathrm{HCl}, \mathrm{pH}$ $8.8,50 \mathrm{mM} \mathrm{KCl}, 15 \mathrm{mM} \mathrm{MgCl} 2,0.1 \%$ Triton X100, 0.01\% gelatin with $90 \mathrm{mg} / \mathrm{ml}$ proteinase $\mathrm{K}$ ) on a glass slide and then cut into small pieces by using a sterilized syringe needle under a dissecting microscope. Each sample was incubated at $60^{\circ} \mathrm{C}$ for $1 \mathrm{hr}$ and then at $95^{\circ} \mathrm{C}$ for 10 min. The crude DNA isolated from each individual nematode was directly amplified. The amplification of the ITS region was performed using the $18 \mathrm{~S}$ forward primer (5'-TGATTACGTCCCTGCCTTT-3') and the 26S reverse primer (5'-TTTCACTCGCCGTTACTAAGG-3') [10], D2-D3 expansion segments of 28S rDNA were amplified using D2A (5'-ACAAGTACCGTGAGGGAAAGTTG-3') and D3B (5'-TCGGAAGGAACCAGCTACTA-3') (Nunn 1992), 18S rDNA using $18 \mathrm{SnF}$ (5'-TGGATAACTGTGGTAATTCTAGAGC-3') and $18 \mathrm{SnR}$ (5'-TTACGACTTTTGCCCGGTTC-3') primers [11]. PCR cycling conditions used for amplification were: an initial denaturation at $94^{\circ} \mathrm{C}$ for $5 \mathrm{~min}$, followed by 35 cycles of denaturation at $94^{\circ} \mathrm{C}$ for 50 s, annealing at $55^{\circ} \mathrm{C}$ for 50 s and extension at $72^{\circ} \mathrm{C}$ for $1 \mathrm{~min}$ and a final step at $72^{\circ} \mathrm{C}$ for 7 min [9]. Following DNA amplification, $10 \mu \mathrm{l}$ of PCR product was used for electrophoresis in $1 \mathrm{X}$ TBE buffer [12,13] in $1 \%$ agarose gel. A $100 \mathrm{bp}$ ladder (Fermentas, St. Leon-Rot, Germany) was used as size marker. PCR products from individual nematodes were purified using the protocol listed by manufacturer (NucleoSpin Gel and PCR Clean-up, Machery Nagel, Germany). Purified ITS, D2-D3 and 18S rRNA fragments were cloned in pGEM-T Easy Vector Systems (Promega, France) and sequenced at Eurofins genomics (Germany). ITS-RFLP analyses were performed on $10 \mu \mathrm{l}$ of PCR products from individual nematodes using five units of the following restriction enzymes: Dde I, Rsa I, Alu I, Hinf I (Promega, France). The restricted fragments were separated on a $2.5 \%$ agarose gel by electrophoresis. The gels were stained with gel red and visualized on a UV transilluminator and photographed with a digital system.

\section{Results}

Entomopathogens were recovered from 34 of 36 soil samples collected (94.4\%): EPN strains were isolated in 8 sites and identify as Heterorhabditis bacteriophora Poinar. Strains of EPF were recovered from 26 soil samples (Table 1), Lecanicillium W. Gams \& Zare came out from 6 soil samples (N. 1, 3, 5, 9, 19 and 22), Aspergillus Micheli from 2 soil samples (N. 9 and 19), Fusarium Link from N. 19 only and Beauveria Vuill. from 16 soil samples; strains of Bacillus thuringiensis (EPB) were isolated from 5 soil samples. In 4 samples more than one pathogen strain was recovered: from N.1 and N.5 H. bacteriophora and Lecanicilium sp., from N.9 Lecanicillium sp. and Aspergillus sp., and from N.19 three fungal strains Lecanicillium sp., Aspergillus sp. and Fusarium sp., with the first two isolated from the same larva. All the pathogen strains were recovered from different habitats and no correlation between the pathogen recovery and the characteristics of the sampling sites was observed, confirming the ubiquity of these entomopathogens.

\section{Discussion and Conclusions}

The presence and occurrence of entomopathogens is a key factor on the biological soil quality and these results represent a small contribution to the knowledge of the Arasbaran biodiversity also considering the methodology used for the pathogens isolations. The recovering of almost $95 \%$ of positive samples to infection was due to the combined used of baiting larvae for static and mobile entomopathogens; considering the ubiquity of these organisms, this modified baiting technique has maximized the possibility of insulation of entomopathogens from the soil.

\section{Acknowledgment}

The research was carried on in the framework of "Della Valle research program" between the Universities of Bari "Aldo Moro" (Italy) and Tabriz (Iran).

\section{References}

1. Poinar GO Jr (1990) Taxonomy and biology of Steinernematidae and Heterorhabditidae. Entomopathogenic Nematodes in Biological Control. In: Gaugler R, Kaya HK (eds.) Boca Raton Fl, USA. CRC Press, pp: 23-61.

2. Poinar GO Jr (1979) Nematodes for Biological Control of Insects. CRC Press, Boca Raton, Fl: 277.

3. Nikdel M, Niknam G, Griffin C, Kary NE (2010) Diversity of entomopathogenic nematodes (Nematoda: Steinernematidae, Heterorhabditidae) from Arasbaran forests and rangelands in north-west Iran. Nematology 12: 767-773.

4. Nikdel M, Niknam G, Ye W (2011) Steinernema arasbaranense sp.n. (Nematoda: Steinernematidae, a new entomopathogenic nematode from Arasbaran Forest, Iran. Nematol Medit 39: 17-28.

5. Seifinejad A, Salehi Jouzani GR, Hosseinzadeh A, Abdmishani C (2008) Characterization of Lepidoptera-active cry and vip genes in Iranian Bacillus thuringiensis strain collection. Biological Control 44: 216-226.

6. Salekjalali M, Barzegari A, Jafari B (2012) Isolation, Pcr Detection and Diversity of Native Bacillus thuringiensis Strains Collection Isolated from Diverse Arasbaran Natural Ecosystems. World Applied Sciences Journal 18: 1133-1138.

7. Tarasco E, Clausi M, Rappazzo G, Panzavolta T, Curto G, et al. (2015) Biodiversity of entomopathogenic nematodes in Italy. Journal of Helminthology 89: 359-366. [crossref]

8. White GF (1927) A method for obtaining infective nematode larvae from culture. Science 66: 302-303.

9. De Luca F, Fanelli E, Di Vito M, Reyes A, De Giorgi C (2004) Comparison of the sequences of the $\mathrm{D} 3$ expansion of the $26 \mathrm{~S}$ ribosomal genes reveals different degrees of heterogeneity in different populations and species of Pratylenchus from the Mediterranean region. European Journal of Plant Pathology 110: 949-957.

10. Vrain TC, Wakarchuck DA, Levesque AC, Hamilton RI (1992) Intraspecific rDNA restriction fragment length polymorphism in the Xiphinema americanum group. Fundamental and Applied Nematology 15: 563-573.

11. Kanzaki N, Futai K (2002) A PCR primer set for determination of phylogenetic relationships of Bursaphelenchus species within xylophilus group. Nematology 4: $35-41$.

12. Sambrook J, Fritschi EF, Maniatis T (1989) Molecular cloning: a laboratory manual (2ndedn), Cold Spring Harbor Lab Press, New York.

13. Glare TR, Jurat-Fuentes JL, O’Callaghan M (2017) Chapter 4: Basic and Applied Research: Entomopathogenic Bacteria. Microbial control of Insect and mite pests. Academic Press, pp: 47-6.

Citation:

Eustachio Tarasco, Naser Eyvasian Kary, Elena Fanelli, Davoud Mohammadi, Ali Mehrvar, et al. (2020) Survey on Entomopathogens from the Arasbaran Biosphere Reserve (Iran) with a Modified Bait Insect Technique. Geol Earth Mar Sci Volume 2(2): 1-3. 